\title{
Season of Migration to Remote Language Learning Platforms: Voices from EFL University Learners
}

\author{
Abdelrahman Abdalla Salih ${ }^{1} \&$ Lamis Ismail Omar ${ }^{1}$ \\ ${ }^{1}$ College of Arts and Applied Sciences, Dhofar University, Salalah, Sultanate of Oman \\ Correspondence: Abdelrahman Abdalla Salih, College of Arts and Applied Sciences, Dhofar University, Salalah, \\ Sultanate of Oman.
}

Received: September 30, 2020

Accepted: November 14, 2020

Online Published: November 19, 2020

doi:10.5430/ijhe.v10n2p62

URL: https://doi.org/10.5430/ijhe.v10n2p62

\begin{abstract}
The abrupt disruption of the traditional face-to-face language instruction due to the unprecedented COVID-19 pandemic has forced many schools and higher learning institutions in Oman and around the globe to establish a virtual learning environment. This crisis-prompted remote learning has been a new experience for most teachers and students alike, a variable that may affect students' learning. Thus, it is significant to understand the students' experience with online teaching and learning. This study explicitly examines online teaching and learning as perceived by English as a Foreign Language (EFL) students of a higher learning institution in Oman. A total number of (112) undergraduate students in Oman acted as a data source by responding to a computer-assisted survey questionnaire. The survey focused on the following themes: overall first-time online language learning experience; online courses; online learning mode and attainment of graduate attributes; effectiveness of online teaching and delivery; utilization and usefulness of electronic learning devices; and e-learning language skills. The findings highlight the significance of exploring learners' online learning experience and its implications for planning, implementing, teaching, and assessing online language education.
\end{abstract}

Keywords: online learning, learner experience, EFL, perceptions, feedback

\section{Introduction}

\subsection{Background to the Study}

In recent years, no external event has brought sweeping effects on education like the onset of the COVID-19 pandemic. On March 11, 2020, the World Health Organization (WHO) characterized the coronavirus as a pandemic and urged for the world's quickest and affirmative response and action. Amid fear, confusion, and uncertainty, schools and higher education institutions in the Sultanate of Oman and around the world had no choice but to transform the onsite or blended instruction to online instruction forcefully.

Before the coronavirus outbreak, navigating to online education systems was still an option that a limited number of universities worldwide would consider at their own pace, especially in Arab and developing countries where academics, students, and the public at large seem to undervalue online education (Ko, \& Rossen, 2017; Vai, \& Sosulski, 2011; Elbelazi, 2015). Over the past ten years or so, there have been endeavors "to publicize and popularize e-learning" (Al Musawi, 2010, p. 604) in the Sultanate of Oman as a potential "alternative" mode of education "in order to increase University admissions of Omani high school graduates” (Al Musawi, \& Akinyemi, 2002, p. 55), and eventually, respond to the "social demand to increase the higher education intake" (Al Musawi, 2010, p. 603).

Such endeavors have been met with several challenges including, but not limited to, updating the educational environment, responding to training needs, and most importantly, the issue of "quality" (Al Musawi, 2010, p. 550; Al Musawi, \& Akinyemi, 2002, p. 56) which was one of the main pillars of the National Strategy for Education 2040 in Oman, as stated by the Education Council (2018) (see https://www.educouncil.gov.om/downloads).

With the disruptive mutations that have affected all countries globally, online education has shifted from being an alternative to a fait accompli, giving little time to academic institutions to consider adopting virtual education as an all-inclusive, one-size-fits-all solution. So, while the coronavirus crisis has reinforced the principle of physical distancing, virtual education has emerged as an ideal strategy to eliminate the physical and geographic miles between academic institutions and students worldwide. 
As a university which accommodates more than 5000 students, Dhofar University (D.U.) in Oman (see https://www.du.edu.om/faq/) responded to the repercussions of the emergency promptly, and within a short notice, shifted from face-to-face education to distance learning while facing a surge of resistance from students, families, and teaching members of staff alike. Now that D.U. has implemented virtual education during the two semesters of Spring and Summer, it has become essential to research this pilot, emergency-enforced experience, and evaluate it, especially that the coming term does not seem to be promising in terms of traveling back to the earlier form of face-to-face education. This research examines the challenges and prospects of implementing online education at D.U. based on an experimental study that surveys D.U.'s EFL students' perceptions about their online learning experience after completing two semesters of emergency online learning.

The rapid expansion of online education environments since its emanation in the 1990s is a paradigmatic shift and a salient characteristic of language learning in the 21 st-century. Research in technology-enhanced language learning showed that "over the last 20 to 30 years, language learning has become one of the most popular and dynamic areas of education for the application of learning technologies" (Thomas, Reinders, \& Warschauer, 2013, p. 26). Thus, the shift of focus from the traditional face-to-face language teaching to digital-enhanced language instruction has increasingly gained momentum both in theory and practice over the years.

Nevertheless, earlier research on L2 distance learning was limited to investigating the various uses of diverse websites and applications in learning a language with little focus on teaching practices and L2 learning standards from a pedagogical angle, which makes it difficult to generalize on the effectiveness of distance learning for language teaching and learning. In the current educational environment where the whole academic process on the tertiary level, including teaching foreign languages, is taking place electronically, at least temporarily, there is no question that L2 distance learning needs to be researched vis-à-vis the parameters of pedagogical practices and language learning standards. There is a need for such a move because "successful distance-learning programs are based on the development of proficiency, within standards-based approaches to language instruction” (Shrum, \& Glisan, 2010, p. 472).

Distance learning is an official educational process in online classrooms where the Instructor and learners meet virtually while present in different places (e.g., Ko, \& Rossen, 2017; Blake, 2008; Bach, Haynes, \& Smith, 2007). Before the COVID-19 crisis, distance learning appeared as "a solution for the limited availability of foreign language teachers, especially for students in remote locations" (Shrum, \& Glisan, 2010, p. 471). In the post-COVID-19 era, distance learning became the only solution to provide education in most countries during lockdown times, and this may happen once again in the future.

No one would deny that education is a fast-paced, rapidly-transforming profession facing exponential challenges with far-reaching effects triggered by the coronavirus outbreak. An article published by Carey in the New York Times on March 13, 2020, under the title "Everybody Ready for the Big Migration to Online College? Actually, No" dealt with the insurmountable challenges of the sudden switch to online education, explaining how "good online education is easier said than done" This conceptualization of the abrupt shift from face-to-face education to online education in terms of the migration metaphor speaks volumes about the complexities of the process for all involved parties. Let us take the online educational process at face value. We may tend to subscribe to the notion that 21 st-century learners are "digital natives" (Prensky, 2001 as cited in Shrum, \& Glisan, 2010, p. 449) who "have grown up using the internet and other technological devices" (Shrum, \& Glisan, 2010, p. 449). In contrast, teachers are the "digital immigrants" (Shrum, \& Glisan, 2010, p. 450) who will suffer in the journey to redefine their educational experiences and pedagogical practices while shaping new ones. The experience has shown that this migration has been arduous and unsettling for institutions, teachers, and students alike.

Delivering education via the Internet is not a new phenomenon now that this form of education has been a part of learners' and teachers' experience for nearly two decades (Ko, \& Rossen, 2017). Nevertheless, the unexpected and unplanned shift to online education may have created an impression that a novel educational model would mark the downfall of a robust educational system on which the sun will never set. This shock-generated impression was all the more true when it came to L2 teaching online, given the entrenched "misconception about technology and language learning" (Blake, 2008, p. 8).

\subsection{Opportunities}

While the dominating impression in L2 learning contexts is that of having to deal with intractable challenges and a sea of issues that go beyond the limitations of time and the urgency of the situation, some linguists still see the crisis as "an opportunity to more intentionally connect with other language users through digital means" (Guillen, Sawin, \& Avineri, 2020, p. 321). Up to date, the literature and academic experiences on teaching foreign languages via the 
Internet reveal that online foreign language courses have recognized new opportunities that face-to-face education may not be able to capture.

By and large, online language education is characterized by flexibility and the ability to promote individualized learning, interactive communication tasks as well as self-learning (Gacs, Goertler, \& Spasova, 2020). For a start, online education provides a versatile educational environment for instructors and learners alike (see Ko, and Rossen, 2017, p. 29). The fact that learners and instructors can participate in the educational process from any place and at relatively convenient timings gives flexibility to the "classroom climate in terms of enjoyment and comfort" (Shrum, \& Glisan, 2010, p. 454). It makes higher education accessible to a broader spectrum of learners and educators who find difficulties in telecommuting to their universities daily. Additionally, online language courses open new horizons for language learners and instructors to explore unlimited resources, which "might be the next best alternative to actually going abroad" (Blake, 2008, p. 4). This alternative has further cognitive implications for both parties of the educational process (learners and instructors) as they will have the opportunity to develop digital literacies while browsing the Internet for information, exchanging knowledge, navigating websites, contributing to blogs or Wikipedia, creating new content, and editing existing content, among others. (Shrum \& Glisan, 2010).

From a communicative perspective, L2 online learning offers diverse opportunities for direct interaction. In an educational environment, there are three levels of interaction: "(1) student-student interaction, (2) student-instructor interaction, and (3) student-content interaction" (Moore, 1989 as cited in Abrami et al., 2012, p. 52). Since the first two types of interaction occur between human beings, it is better to explore them under 'communication' after discussing the level of interaction between learners and content. Blake investigated the possibilities of employing technologies in foreign language learning by upscaling the interaction between L2 learners and the target language and culture, based on the Second Language Acquisition (SLA) principle, which views interaction as a solid foundation for learning a foreign language. Technologies play a significant role in bolstering learners' interaction with target language content by exposing them to diverse cognitive and cultural scenarios that they would otherwise have access to only by traveling abroad (Blake, 2008). Such content includes audiovisual multimedia resources such as educational websites, television series (educational or otherwise), youtube content, social media content, podcasts, to name a few.

The role of technology in student-content interaction can be invigorated in L2 online courses in different ways that develop learners' ability to "negotiate meaning with other learners and/or native speakers" in the target language (Blake, 2008, p. 10). Shrum and Glisan explored the implications of using technology by foreign language learners and teachers, highlighting the relevant opportunities and challenges vis-à-vis several standards adopted in teaching languages online. L2 teaching is fundamentally anchored in the concept of communication as an essential requirement to build and improve students' skills "in reading, writing, speaking, and listening among varied cultural contexts" (Shrum, \& Glisan, 2010, p. 451). In online education, the concept of communication associates with the term Computer-Mediated Communication (CMC) (see Shrum, \& Glisan, 2010, p. 460). CMC may take place synchronously or asynchronously (Chapelle, 2003). Students can invest in different LMS functions like chats and online group work, or they can communicate with each other and with their instructors by uploading recorded messages or videos or contributing to "discussion forums, or electronic bulletin boards, blogs, wikis, and chatting with or without sound/video" (Blake, 2008, p. 70).

Students can engage in collaborative activities asynchronously via tandem projects (Gonzales-Lloret, 2020; Guillen et al., 2020). A tandem collaboration is an informal venue for learners from different languages and cultures to exchange language learning activities. Language exchange programs are valuable for enhancing students' communicative skills as they involve them in inevitable, culturally-enriched, meaning negotiation exchanges (Ross, \& DiSlavo, 2020). Similarly, L2 learners can develop interpersonal exchanges on social media, which "offer the means to make L2 learning relatable, relevant, and accessible" (Reinhardt, 2020, p. 240). Such venues reinforce students' "autonomous learning skills to direct their own learning, as they engage in L2 learning activity on their own outside of the teacher's sight" (Reinhardt, 2020, p. 235). Some linguists investigated the role of games as a pedagogical strategy "to facilitate language learning in the age of social distancing" (Dubreil, 2020, p. 257).

Although informal, asynchronous exchanges which involve "communication and information access, simulation, gaming and personal learning environments (that were unthinkable just a few years ago) are becoming mainstream" (Moller, Robinson, and Huett, 2012, p. 3), the main reservation one may have on them is that they take place beyond the official academic framework in a way that neither instructors nor academic institutions can have control over their scope or content. While technology provides a treasure of resources to all those interested in learning a second language, any available opportunities and resources to be integrated with L2 courses need to be considered from the 
perspective of "a well-developed and methodologically sound curriculum, based on language acquisition research findings" (Gonzales-Lloret, 2020, p. 267).

Kent (2015) explored mobile phones' uses in formal and informal language learning contexts as a flexible, interactive, and affordable educational means, highlighting the role of pedagogy, course design, and teaching methodologies as the main components behind the success or failure of the educational process. The researcher concluded that mobile phones provide an acceptable means of education, particularly in language learning, as long as they have regular access to a stable network and a carefully-designed course content that responds to their educational needs and enhances their interaction and autonomous learning skills (p. 14). Mobile phones provide a handy, though not ideal, technological means to bridge a temporary digital gap among learners and make online education within reach of a wider variety of students. In the context of the COVID-19 crisis, mobile phones' role in online education was mainly discussed vis-àvis their function in informal, asynchronous activities (see Guillen et al., 2020). Nevertheless, there is no denying that they were used by students on a large scale as a makeshift solution to take part in the online educational process during lockdown periods, particularly in countries that were not involved in any "contingency planning" (Ross, \& DiSlavo, 2020, p. 372) such as developing countries and some countries in the Arab world.

\subsection{Challenges}

Ko and Rossen (2017) investigated the obstacles that cause learners' tension in an online environment. These include using outdated equipment and browsers, facing technical issues while accessing or downloading materials or software, the lack of experience in autonomous learning and online communication, the absence of direct human interaction between instructors and learners, delayed feedback, among others. The writers suggested that instructors can address these issues by integrating individual components with the educational process. For instance, they can post short video recordings and require them to do the same for their assignments. Additionally, instructors need to maintain real-time communication during synchronous sessions and constant and prompt communication via asynchronous means such as emails, forum discussions, LMS venues, to mention a few. All these strategies enhance "the interpersonal values of instruction" (Gibbons \& Griffiths, 2012, p. 31), which are of extreme significance in an increasingly-growing, semidetached e-learning environment.

During the crisis, all those involved in the educational process need to think outside the box. In an article that discussed the challenges of switching from face-to-face education to crisis-prompted online education, Gacs et al. (2020) dwelled on the components that need updating during the transitional period. These components comprise delivery format (synchronous/asynchronous); platforms (LMS/CMS such as Blackboard or Moodle); course design (a backward design which starts with the learning objectives backward); course organizational structure (per weeks or book chapters/topics); skills and interaction modes (listening, reading, speaking and writing); and assessment methods, evaluation plan (course review, learning outcomes, assessment methods, instructional methods and content, activities and learner interaction, learner support, technology, to mention a few).

Updating these components imposes multifaceted challenges that emerge during implementation, and these include establishing robust communication modes, instructor visibility, and authenticity, constructing a community of learners, updating and improving types of feedback, time management strategies, teaching students about online learning strategies (Gacs et al., 2020). One of the challenges students face when switching to virtual education is the lack of educational means, namely computers. It is widely recognized that not all students have computers or can afford to buy one, which was one reason why many families and students resisted the full shift to online education at the height of the crisis. Although computers are the most convenient means for online education, learning online does not necessarily have to be conducted via a computer. Shrum and Glisan (2010) used "the term Technology-Enhanced Language Learning (TELL) to refer to all uses of technology in language education" (p. 452), while other researchers referred to "mobile-assisted language learning (MALL)" (Guillen et al., 2020, p. 321) as a strategy for integrating informal self-learning with formal online education in synchronous classes.

Another challenge that encounters online education is low learner motivation due to the lack of a physical visuallyenhanced learning environment. To bridge this gap, instructors need to be creative in communicating with their students and designing tasks that boost their motivation and active involvement in the educational process. Communicating with students online needs to be revived by activating specific strategies like using visual components (pictures, videos), writing to students to encourage them, using a clear and concise writing style, and setting up online office hours for the Instructor to communicate with their students by phone, video, and chat (Vai, \& Sosulski, 2011). Another strategy that instructors can employ to keep their learners motivated and focused on their activities is task engagement, which is highly effective "when learners may be experiencing fear and chaos in other aspects of their lives" (Egbert, 2020, p. 315). In L2 distance learning, task engagement has a different nature as it needs facilitating 
factors that help learners maintain an adequate level of engagement with the tasks assigned to them: 1 . task relevance which means involving the students in assignments on a relevant topic (from the latest news, for instance); and 2. task authenticity which means that the task is entirely meaningful and useful for the learners beyond their academic context.

There is a rich variety of target language resources that can boost students' motivation like WebQuests, mobile phone applications, T.V. shows, cartoons, to name a few (Egbert, 2020). Students can also be asked by their instructors to use their L2 to engage in stories of their interest asynchronously on social media platforms, which makes them "hungrier for explanations in their synchronous classes" (Guillen et al., 2020, p. 323) and more motivated when target language users follow them or interact with their input. Also, instructors can keep students motivated in the L2 online classroom by integrating Virtual Reality (V.R.) applications with synchronous teaching. In this regard, instructors may choose to use software such as Google Expeditions and career-related Expeditions as virtual vehicles to transfer the learners to new realms of language learning, "focusing on subject matters such as science, history, and literature. Moreover, Expeditions are useful in practicing the use of a grammatical form such as there is/there are while asking students to describe what they see in the V.R. environment" (Alizadeh, 2019, p. 27). The use of V.R. in the L2 classroom is still not widespread yet, but people can explore it and adapt it to meet the needs of different L2 learning aspects (Alizadeh, 2019).

In a distance-learning environment, "gestures, body language, a common physical experience, and often even facial expressions are missing" (Gacs et al., 2020, p. 382), and students cannot participate in face-to-face interaction with their instructors and peers, which creates difficulty in building a class community (Payne, 2020). Building a community of learners is of paramount importance for a successful educational process. Unless students feel they are part of a well-connected group of learners, they can easily fall prey to negative feelings of isolation and lack of confidence, and this can result in "low achievement or even dropping out" (Gonzales-Lloret, 2020, p. 264). The importance of having a robust and well-connected class community increases considerably in L2 learning because it promotes certain pedagogical aspects related to an indispensable component of the L2 curriculum: developing all four skills (reading, writing, listening, speaking) equally. Although online L2 classrooms are supposed to be more interactive and learnercentered, students' involvement in activities that develop their productive skills (speaking and writing) is below the required level. Blake (2008) questioned distance learning's ability to enhance learners' speaking skills (p. 115). However, it is not an academically-sound argument to "disregard four decades of Second Language Acquisition research because it is difficult to incorporate speaking in our online foreign or second language (L2) curriculum" (Gonzales-Lloret, 2020, p. 261), especially that teaching language nowadays is mainly focused on "oral proficiency" (Blake, 2008, p. 115).

This issue was elaborated by several linguists who dealt with diverse strategies to enhance L2 students' productive skills. Some researchers maintained that the process could take place synchronously where instructors can invigorate learners' interaction by "Reserving synchronous class-time (...) and integrating tools and services such as Talk Abroad, Flip Grid, Voice Thread, or Padlet” (Gacs et al., 2020, p. 386). On the other hand, others advised instructors to adopt asynchronous strategies by developing tasks for learners to post or publish "their written and oral work on the World Wide Web where others can access it" (Chapelle, 2003, p. 25). Any strategy proposed to enhance students' productive skills needs to be inspired by strengthening students' online communities. Some researchers invested in the principles of "collaborative and cooperative learning" (see Abrami et al., 2012, p. 60) to propose a model of online learner-learner interaction that promotes L2 learning skills. Gonzales-Lloret (2020) discussed the concept of 'collaborative learning' as a foundation for using collaborative technology-mediated tasks that improve students' productive skills. For instance, students can be asked to talk about their daily routine or a specific personal experience/story using video conferencing or online chat. Such tasks can be fruitful not only in promoting productive language interaction in class but also in "building a community of learning" (Gonzales-Lloret, 2020, p. 262). Payne (2020) addressed the two challenges of developing productive language skills and building a vibrant e-learning community by proposing the strategies of pre-task planning and sequencing activities. Pre-task planning is conducted asynchronously by posting materials and activities that familiarize the students with the learning context. This strategy has proved incredibly successful in promoting learners' performance in productive skills because it helps to "reduce the cognitive load" (p. 245).

The sequencing of activities consists of a series of asynchronous and synchronous tasks, including pre-task planning, peer feedback, exchanging views, and a video conference or chat online. By that time, students will have had the chance to brainstorm and verbalize their input at their pace. This strategy does not apply only to learners' activities, as it is also necessary for instructors teaching activities. Instructors can choose to split their teaching content into small lectures "using a microlearning approach, possibly with short, auto-scored quizzes after each minilecture" (Payne, 2020 , p. 246). From a cognitive perspective, it is expected that this gradation in exposing online learners to their 
teaching content and preparing them for their activities "can produce improved learning outcomes and provide an instructional routine that can be reassuring" (Payne, 2020, p. 247) for them.

Some researchers discussed the vital role of educators in creating "a learning community" (Ross, \& DiSlavo, 2020, p. 373) or language communities. Instructors need to ensure that they are present, authentic, and capable of interacting with their students vividly (Lomicka, 2020). These teacher-related traits can be reflected by adopting some steps that guarantee teachers' availability during specific time slots (office hours) and their involvement in students' activities synchronously (chat and video conferencing) and asynchronously (email, forum discussions, breakout rooms, conducting polls). Fundamentally, instructors also need to show their authenticity by sharing individual stories from their personal experience or photos and videos that deal with a specific topic via weekly emails or on the official LMS, which "can help to establish feelings of connectedness and build community" (Lomicka, 2020, p. 309).

However, "who has the time for that kind of an investment" (Blake, 2008, p. 13), some teachers may ask. Contrary to the prevalent assumption among learners and academic institutions with limited or fresh online education experience, teaching online courses increases instructors' workload considerably because they will be working with their students online and offline. This situation explains why "it is important to have realistic expectations about the working load that online courses produce for teachers, the possibility that remote participants have for synchronous connection, the amount of feedback that students will receive, as well as the type and amount of evaluation that can be done through technology" (Gonzales-Lloret, 2020, p. 267). Instructors can surmount this challenge by replacing part of synchronous teaching with asynchronous content. Accordingly, they will have more time to prepare and upload offline materials, while the online session can be dedicated to reduced discussions about basic concepts, giving practical examples, allowing for students' contributions, and giving them relevant feedback. This strategy was described as the "flipped approach to instruction" (Ross, \& DiSlavo, 2020, p. 373).

Although research has shown that L2 online learning is an emerging field that has gained ground at an accelerated pace over the past few years, many aspects await researchers' prompt and undivided attention under the current crisis. For instance, researchers need to broaden our understanding of evidence-driven instructors' pedagogical practices in the virtual academic environment and, most importantly, empirical-based learners' evaluation of their experience in ESL/EFL online learning. This study attempts to explore EFL university students' perceptions of their online learning experience in Oman with particular reference to their experience in the courses they studied, their attainment of graduate attributes, course delivery and teaching methods, the usefulness of electronic devices, and possible challenges encountered in using such devices, as well as language skills development. The study strives explicitly to address the following questions:

1. How do language learners perceive crisis-prompted distance learning?

2. What implications might students' involvement in online learning have on learning a foreign language?

\section{Method}

The present study is exploratory as it investigates university students' perceptions about their first-hand experience with online language learning in an EFL context in the Sultanate of Oman. The study examines learners' experiences in learning English via the distance learning mode, focusing on perceptual aspects of learning rather than productive outcomes.

\subsection{Participants}

This study's subjects comprised a group of $(\mathrm{N}=112)$ EFL undergraduate learners at a higher learning institution in Oman. In terms of the online learning experience, these students are familiar with Moodle as an official learning management system at the university but had not experienced full-term distance learning before except for the previous Spring and Summer Semesters. The procedure for data collection was discussed below.

\subsection{Data Collection Procedure and Analysis}

\subsubsection{Questionnaire}

The current study explored the students' perceptions of their experience in online learning. The study utilized one primary source of data: a computer-assisted survey questionnaire. According to Sue \& Ritter (2007), "online surveys are similar to self-administered paper-and-pencil questionnaires" (p. 39). Questionnaires are commonly used as data collection instruments, particularly in second language learning research. Vehovar \& Manfreda (2017) remarked that "survey data collection-based on standardized questionnaires delivered to a sample (or the whole of the target population)-is an important data collection tool in a variety of contemporary research fields" (p.143). Thus, "a survey question is a measurement tool, a way for researchers to discover a respondent's opinion, knowledge, and behavior" 
(Sue, \& Ritter, 2007, p. 38). The survey questionnaire, utilized by the current study and administered to (N=112) university EFL learners, was designed to explore students' perceptions of their online learning experience. The questionnaire contained six themes: (1) respondents' views about their first time online learning experience (11 questions), (2) their attitudes towards online courses (10 questions), (3) their attainment of graduate attributes via the online learning mode (6 questions), (4) their views on the Instructor (8 questions), (5) their experience with electronic learning devices (laptops, mobile phones, and tablets) in terms of use, usefulness, and level of difficulty in use, and (6) their views on learning language skills. The questionnaire items were arranged thematically on a five-point scale of Strongly Disagree, Disagree, Uncertain, Strongly Agree, and Agree. The questionnaire used a linear scale format to elicit participants' experience with electronic learning devices and learn language skills. The participants were instructed to click the items they prefer to add their opinions to the survey. The responses elicited from the participants form an essential source of feedback for a more practical context for the ways by which online language learning can be planned, designed, implemented, and evaluated.

\section{Results and Discussion}

In total, 112 responses to the questionnaire survey were received. The students' survey frequency counts of 'Strongly Disagree' and 'Disagree' were combined with 'Strongly Agree' and 'Agree' for appropriate analysis and discussion. The findings of the analysis of the participants' responses to the questionnaire questions were discussed under the learners' overall perceived experience in online learning, the content of courses, achieving graduate attributes, teaching style, electronic learning devices, and language skills development and level of learning difficulty as shown in the following:

\subsection{Overall Online Language Learning Experience}

The analysis results revealed that over 55\% of the participants held complimentary views about distance learning as comfortable, while $29 \%$ disagreed, and $15 \%$ appeared uncertain. Around $47 \%$ of the respondents indicated that online learning was motivating, while $33 \%$ did not hold the same view, and $18 \%$ were uncertain. On the other hand, $62 \%$ of the participants stated that online learning involved difficulties that made it a challenging experience, and only $20 \%$ disagreed. This result reflects the fact that the participants did not have prior experience with full-time online learning. Over $47 \%$ of the surveyed participants were not in favor of their University switching to full-time virtual learning compared to $37 \%$ who supported the idea, while $15 \%$ reported uncertain views. This finding is significant because it reveals the cultural constraints e-learning and its electronic educational platforms might have in conservative contexts like Oman, where students' participation in electronic learning platforms is disfavored. When asked about their digital materials experience, over $60 \%$ of the participants stated that online learning motivated them to explore more online resources and materials, while $25 \%$ did not think so, and $13 \%$ remained uncertain. Interestingly, over $50 \%$ of the students surveyed stated that they were more comfortable reading online materials than paper texts, while $38 \%$ disagreed. The majority of the participants' complimentary views about the opportunities distance learning offered with online learning materials suggest that students continue to learn even outside their classes. This expansion of learning outside the classroom is considered an advantage that learners might avail of to maximize their learning and academic growth.

Distance learning has improved the students' communication skills and encouraged them to use emails to communicate with their academic advisors and instructors. Over $65 \%$ of the participants found improvement in their email writing and communication skills. Similarly, $51 \%$ of the students found that online learning facilitated writing assignments and academic writing improvement, while $27 \%$ revealed the opposite. On another aspect, over $65 \%$ of the students surveyed reported that online learning fostered collaboration among them in academic materials sharing, while 23\% did not see online-learning-based collaboration among classmates. The results also reveal that over $51 \%$ of the students reported that online learning helped them sharpen their English language skills, while 28\% did not positively see any impact on their language skills. Overall, the results above show that online learning is a fertile environment for building a robust community of learners and improving writing's productive skills. These two aspects of second language learning go hand in hand in providing a successful collaborative learning model, as the literature review discussed earlier.

\subsection{About the Course}

It is of paramount importance to seek learners' views on the courses they study, mainly through an unconventional way, such as distance learning. Over $57 \%$ of the surveyed students indicated that online learning enabled them to learn about all the essential aspects of their courses, while 30\% disagreed. Also, around $47 \%$ of the participants confirmed that distance learning made them realize how important and useful the course syllabus document is, but $25 \%$ reported the opposite view. In the same context, over $63 \%$ of the students revealed that they found the course syllabus document 
helpful in planning online classes. This finding is significant because it indicated the students' motivation for online learning, preparation, and willingness to learn beyond the classroom context. The participants also were satisfied with the online course content coverage. Over 50\% indicated that digital learning facilitated covering the course content during the semester, while $26 \%$ disagreed. The results also show that $47 \%$ of the students agreed that online learning helped them achieve the intended course learning outcomes, and $25 \%$ responded negatively. Exploring language learners' views on the degree of success in achieving course learning outcomes is significant for quality-enhanced learning.

Similarly, over $62 \%$ of the students stated that their online learning experience enabled them to understand the importance of course learning outcomes better. Only $18 \%$ of the participants disagreed. The analysis also reveals that over $63 \%$ of the students were satisfied that online learning made teaching materials such as handouts available and facilitated learning the subjects they studied. This finding is crucial as it highlights the significance of the asynchronous teaching mode. The students also held a somewhat positive attitude towards their experience with the online assessment system when over $47 \%$ viewed the assessment procedures as adequate and appropriate for assessing the course intended learning outcomes, while $26 \%$ disagreed. This finding implies that a better online assessment mechanism in planning, design, and implementation is imperative.

\subsection{About the Graduate Attributes}

Table 1 below presents the surveyed students' attitudes towards the online learning experience in developing the target graduate attributes.

Table 1. Frequency count and percentage of students' perceptions towards online learning-mastered graduate attributes

\begin{tabular}{|c|c|c|c|c|c|}
\hline \multirow[t]{2}{*}{ Graduate Attribute } & \multicolumn{5}{|c|}{ Attainment Percentage } \\
\hline & S.D $\%$ & $\mathrm{D} \%$ & $\mathrm{U} \%$ & S.A\% & $\mathrm{A} \%$ \\
\hline $\begin{array}{l}\text { Master theoretical knowledge related to the } \\
\text { course commensurate with program level } \\
\text { and objectives }\end{array}$ & $5.4(6)$ & $16.1(18)$ & $18.8(21)$ & $25.9(29)$ & $33.9(38)$ \\
\hline $\begin{array}{l}\text { Master practical skills related to the course } \\
\text { commensurate with program level and } \\
\text { objectives }\end{array}$ & $14.3(16)$ & $7.1(8)$ & $21.4(24)$ & $29.5(33)$ & $27.7(31)$ \\
\hline $\begin{array}{l}\text { Demonstrate the capacity for effective } \\
\text { communication }\end{array}$ & $17(19)$ & $10.7(12)$ & $18.8(21)$ & $25.9(29)$ & $27.7(31)$ \\
\hline $\begin{array}{l}\text { Demonstrate the capacity for practical } \\
\text { critical thinking, creativity, and innovation }\end{array}$ & $15.6(17)$ & 10.1(11) & $14.7(16)$ & $22.9(25)$ & $36.7(40)$ \\
\hline $\begin{array}{l}\text { Exhibit accountability, discipline, and } \\
\text { honesty }\end{array}$ & $5.5(6)$ & $16.4(18)$ & $19.1(21)$ & $28.2(31)$ & $30.9(34)$ \\
\hline Practice life-long learning & $8.3(9)$ & $11.9(13)$ & $24.8(27)$ & $22(24)$ & $33(36)$ \\
\hline
\end{tabular}

Table 1 above reveals that $59 \%$ of the students held a positive attitude about online learning for facilitating attainment of graduate attributes in terms of theoretical knowledge related to the course per the intended program level and objectives. On the other hand, $21 \%$ of the participants disagreed, and $18 \%$ were uncertain about their stand. Over $57 \%$ of the students agreed that online learning helped them to master the practical skills related to their courses, while $21 \%$ scored for both 'disagree' and 'uncertain.' Also, over 53\% of the students stated that online learning helped them to master more effective communication skills, while $27 \%$ did not see an effect on their skills. Over $59 \%$ reported that online learning contributed to developing their critical thinking, creativity, and innovation. $25 \%$ of the students disagreed with the statement, and $14 \%$ remained uncertain. Similarly, over $59 \%$ of the students viewed online learning as a good training opportunity to practice and master accountability, discipline, and honesty. $21 \%$ disagreed, and $19 \%$ were uncertain of their stand. In the same vein, $55 \%$ of the students experienced practicing life-long learning, while $20 \%$ held the opposite view on that. 


\subsection{About Instructor}

Table 2. Frequency count and percentage of students' perceptions towards teaching

\begin{tabular}{|c|c|c|c|c|c|}
\hline \multirow[t]{2}{*}{ Instructor } & \multicolumn{5}{|c|}{ Subjects' Perceptions } \\
\hline & $\begin{array}{l}\text { Almost } \\
\text { Always\% }\end{array}$ & Usually\% & Sometimes\% & Seldom $\%$ & Never\% \\
\hline $\begin{array}{l}\text { Explicit language and } \\
\text { straightforward communication } \\
\text { style }\end{array}$ & $32.1(35)$ & $35.8(39)$ & $19.3(21)$ & $8.3(9)$ & $4.6(5)$ \\
\hline $\begin{array}{l}\text { Responsive to students' } \\
\text { questions }\end{array}$ & $39.1(43)$ & $18.2(20)$ & $30(33)$ & $4.5(5)$ & $8.2(9)$ \\
\hline $\begin{array}{l}\text { Attentive to the 'chat' option in } \\
\text { Moodle }\end{array}$ & $37.3(41)$ & $16.4(18)$ & $35.5(39)$ & $4.5(5)$ & $6.4(7)$ \\
\hline $\begin{array}{l}\text { Use of engaging teaching } \\
\text { method }\end{array}$ & $36.2(38)$ & $24.8(26)$ & $25.7(27)$ & $5.7(6)$ & $7.6(8)$ \\
\hline $\begin{array}{l}\text { Encouraged } \\
\text { participation }\end{array}$ & $40.4(44)$ & $26.6(29)$ & $17.4(19)$ & 6.4 & $9.2(10)$ \\
\hline Provided constructive feedback & $34.9(38)$ & $23.9(26)$ & $15.6(17)$ & 11.9 & $13.8(15)$ \\
\hline $\begin{array}{l}\text { Used clear grading criteria for a } \\
\text { fair evaluation of students' } \\
\text { performance }\end{array}$ & $34.9(38)$ & $25.7(28)$ & $14.7(16)$ & 7.3 & $17.4(19)$ \\
\hline $\begin{array}{l}\text { Adapted teaching materials } \\
\text { commensurate with the online } \\
\text { learning environment }\end{array}$ & $35.8(39)$ & $23.9(26)$ & $22(24)$ & $12.8(14)$ & $5.5(6)$ \\
\hline
\end{tabular}

Table 2 above summarizes the students' attitudes about their instructors concerning online teaching. The majority of the students did not raise significant concerns about their ability to understand their instructors either in teaching or public communication events. Interestingly, the students showed divided views about the way instructors responded to their questions and clarifications. More than $39 \%$ of the respondents stated that instructors were almost invariably receptive to questions and uncertainties, while about $30 \%$ mentioned that instructors were sometimes responsive. Similarly, the students showed the same divided views about their instructors' use and response to Moodle's 'chat' option. Over 37\% stated that instructors almost always consider 'chat' in Moodle and responded to their messages, while $35 \%$ stated that instructors sometimes consider their messages in Moodle 'chat'. The majority of the students stated that teaching online was engaging. The students' most praised teaching aspect was the encouragement for participation instructors rendered them during online learning. Over $40 \%$ of the students stated that their instructors motivated them to participate in class discussions and activities. Teaching online exerts energy, preparation, human touch, and enthusiasm for teachers to engage students and motivate them to learn, especially in the absence of many aspects of traditional face-to-face classrooms. The survey analysis also demonstrates that the students' overall experience indicated their appreciation of the feedback they received from their instructors and the online grading criteria for their performance. Most of the students were also optimistic about how instructors adapted the teaching materials commensurate with the online learning environment. This finding accords with the result reported earlier about the students' satisfaction with the online teaching materials' availability and accessibility.

\subsection{About Electronic Learning Devices}

The students' experience with electronic learning devices covered aspects such as frequency of use, usefulness, and difficulty in use. Results show that $44 \%$ of the surveyed students used laptops, while $32 \%$ used mobile phones, and Tablets were never used by over $47 \%$ of the students. Similarly, the students expressed views on these devices about perceived usefulness for learning and difficulty, as shown in Table 3 below. 
Table 3. Frequency count and percentage of students' perceptions towards e-learning devices

\begin{tabular}{lllllll}
\hline Devices & \multicolumn{3}{c}{ Usefulness } & & \multicolumn{2}{c}{ Difficulty } \\
& Very Useful & Less Useful & Not Useful & $\begin{array}{l}\text { Very } \\
\text { Difficult }\end{array}$ & Difficult & Not Difficult \\
\hline Laptops & $67.9 \%(74)$ & $22 \%(24)$ & $10 \%(11)$ & $15.9 \%(17)$ & $23.4 \%(25)$ & $60.7 \%(65)$ \\
Mobile & $44.5 \%(49)$ & $40.9 \%(45)$ & $14.5 \%(16)$ & $20.8 \%(22)$ & $35.8 \%(38)$ & $43.3 \%(46)$ \\
Phones & & & & & & \\
Tablets & $25.9 \%(28)$ & $36.1 \%(39)$ & $38 \%(41)$ & $22.6 \%(24)$ & $36.8 \%(39)$ & $40.6 \%(43)$
\end{tabular}

The students showed consistency in rating the three e-learning devices in terms of usefulness for learning and difficulty using. As Table 3 above shows, the students held positive perceptions about laptops for being useful and easy to use for learning compared to mobile phones and tablets. Mobile phones were ranked second among the students for simplicity of use in learning. On the other hand, tablets were perceived as the most difficult to use and less preferred by the students. The findings here are significant because they inform future pedagogical plans to design and implement online courses.

\subsection{About Language Skills}

Table 4. Frequency count and percentage of students' perceptions towards language skills

\begin{tabular}{llllll}
\hline Skills & \multicolumn{4}{c}{ Subjects' perceptions } \\
& Very Easy & Easy & Uncertain & Difficult & Very Difficult \\
\hline Reading & $15.5 \%(17)$ & $13.6 \%(15)$ & $28.2 \%(31)$ & $14.5 \%(16)$ & $28.2 \%(31)$ \\
Listening & $12.7 \%(14)$ & $18.2 \%(20)$ & $23.6 \%(26)$ & $21.8 \%(24)$ & $23.6 \%(26)$ \\
Speaking & $14.5 \%(16)$ & $15.5 \%(17)$ & $25.5 \%(28)$ & $14.5 \%(16)$ & $30 \%(33)$ \\
Writing & $17.3 \%(19)$ & $11.8 \%(13)$ & $27.3 \%(30)$ & $16.4 \%(18)$ & $27.3 \%(30)$
\end{tabular}

The students held different attitudes towards their learning language skills online while raising concerns, as shown in Table 4 above. Interestingly, the results show an apparent lack of harmony between the first column and the last column. For instance, according to the first column, the students found writing the most effortless skill to handle online, followed by reading, speaking, and listening. On the other hand, the last column shows that speaking was perceived as the most challenging skill by the students, followed by reading, writing, and listening. This superficial conflict in the results is indicative of serious underlying issues in L2 online learning. First, the fact that the writing skill is ranked as the easiest, contrary to what is expected in normal conditions since it is a productive skill, has to do with the availability of online functions that make writing available to students both synchronously and asynchronously, such as chatting online (in the online classroom) or in forums, sending emails, sending instant messages, and so forth.

Conversely, listening, which is supposed to be the most accessible skill since it is a receptive skill and requires no proactive involvement on the student's part, is ranked last in the first column. This finding can be explained by issues students were having in terms of connectivity and online teaching quality. It suggests that academic institutions' actual work needs to be done by academic institutions in collaboration with government bodies to improve online classes' technical quality. Sometimes, listening may be less easy for students for reasons that have nothing to do with the Internet's low quality. Other reasons may include students' inability to follow with their instructors online as they can be easily distracted due to the lack of visual intervention. This finding highlights the importance of visuals and other means that can keep learners involved and motivated.

Similarly, the last column is expressive of other issues that disrupt other aspects of L2 online learning. For example, speaking is ranked as the top skill in terms of difficulty. This finding goes in line with the literature review discussion of the challenges of teaching a foreign language online. Speaking is the most difficult skill to be improved online because of time limitations and the lack of a useful LMS tool that learners can use synchronously. This observation highlights the importance of devising novel pedagogical strategies or new technical functions that allow the students to improve their speaking skills. Also, it is worth noting in the last column that reading is ranked as the next top difficult skill after speaking, and this is related to the fact that students do not get to practice reading in their online session for the same reasons stated above. 
All in all, there is no doubt that an online learning environment is not conducive to the balance required in teaching all four language learning skills. One interpretation for this is the absence of the conventional interactional mode onsite learning offers compared to distance learning. Without the physical presence of both instructors and students, there will be some limitations in students' participation and interaction with their peers and instructors.

\section{Conclusion}

The current study has examined language learners' experience with online learning in an EFL context in Oman and has highlighted the significance of the students' feedback as crucial stakeholders in the educational activity. A key observation is that students are interested in online learning and hold a positive attitude towards it. Perhaps, among the lessons learned during the COVID-19 pandemic is the necessity of being prepared for a crisis of whatever type. This pandemic was not the first humanity experienced, and it will not be the last, and crisis can hit anytime and without warning. Exploring the students' experience with online learning in extreme circumstances like the coronavirus is crucial for any steps to provide a better context for how language learners' experience might be improved.

\section{References}

Abrami, P. C., Bernard, R. M., Bures, E. M., Borokhovski, E., \& Tamim, R. M. (2012). Interaction in distance education and online learning: Using evidence and theory to improve practice. In L. Moller and J. B. Huett (Eds.), The next generation of distance education: Unconstrained learning (pp. 31-47). Springer. https://doi.org/10.1007/978-1-4614-1785-9_4

Alizadeh, M. (2019). Virtual reality in the language classroom: Theory and practice. CALL-EJ, 20(3), 21-30.

Al Musawi, A. S. (2010). eLearning in Oman. In U. Demiray (Ed.), cases on challenges facing e-learning and national development: Institutional studies and practices (pp. 603-626). Retrieved from https://files.eric.ed.gov/fulltext/ED508255.pdf

Al Musawi, A. S., \& Akinyemi, A. (2002). Issues and prospects of e-learning in Oman. In B. Philip, \& R. Samuel (Eds.), ED-MEDIA 2002 World Conference on Educational Multimedia, Hypermedia \& Telecommunications (pp. 55-56). Association for the Advancement of Computing in Education. Retrieved from https://files.eric.ed.gov/fulltext/ED476959.pdf

Bach, S., Haynes, P., \& Smith, J., (2007). Online learning and teaching in higher education. McGraw-Hill House.

Blake, R. J. (2008). Brave new digital classroom: Technology and foreign language learning. Georgetown University Press.

Carey, K. (2020, March 13). Everybody ready for the big migration to online college? Actually, no. Retrieved from https://www.nytimes.com/2020/03/13/upshot/coronavirus-online-college-classes-unprepared.html

Chapelle, C. A. (2003). English language learning and technology: Lectures of applied linguistics in the age of information and communication technology. John Benjamins Publishing Company. https://doi.org/10.1075/1llt.7

Dhofar University Website: https://www.du.edu.om/faq/

Dubreil, S. (2020). Using games for language learning in the age of social distancing. Foreign Language Annals, 53(2), 250-259. https://doi.org/10.1111/flan.12465

Egbert, J. (2020). The new normal? A pandemic of task engagement in Language Learning. Foreign Language Annals, 53(2), 314-319. https://doi.org/10.1111/flan.12452

Elbelazi, S. (2015). The use of technology in second language literacy: Does it work? Arab World English Journal, 2, 116-123. Available at SSRN: https://ssrn.com/abstract=2843983

Gacs A., Goertler S., \& Spasova S. (2020). Planned online language education versus crisis-prompted online language teaching: Lessons for the future. Foreign Language Annals, 53(2), 380-392. https://doi.org/10.1111/flan.12460

Gibbons, A. S., \& Griffiths, M. E., (2012). Rethinking design and learning processes in distance education. In L. Moller and J. B. Huett (Eds.), The next generation of distance education: Unconstrained learning (pp. 31-47). Springer. https://doi.org/10.1007/978-1-4614-1785-9_3

Gonzales-Lloret, M. (2020). Collaborative tasks for online language teaching. Foreign Language Annals, 53(2), 260269. https://doi.org/10.1111/flan.12466

Guillen, G., Sawin, T., \& Avineri, N. (2020). Zooming out of the crisis: Language and human collaboration. Foreign Language Annals, 53(2), 320-328. https://doi.org/10.1111/flan.12459 
Kent, D. B. (2015). Mobile ELT: East and south of the Red Sea. Arab World English Journal Special Issue, 2, 6-21. https://doi.org/10.2139/ssrn.2843974

Ko, S., \& Rossen, S. (2017). Teaching online: A practical guide (4th ed.). Routledge. https://doi.org/10.4324/9780203427354

Lomicka, L. (2020). Creating and sustaining virtual language communities. Foreign Language Annals, 53(2), 306313. https://doi.org/10.1111/flan.12456

Moller, L., Robinson, D., \& Huett, J. B. (2012). Unconstrained learning: Principles for the next generation of distance education. In L. Moller \& J. B. Huett (Eds.), The next generation of distance education: Unconstrained Learning (pp. 31-47). Springer. https://doi.org/10.1007/978-1-4614-1785-9

Payne, J. S. (2020). Developing L2 productive language skills online and the strategic use of instructional tools. Foreign Language Annals, 53(2), 243-249. https://doi.org/10.1111/flan.12457

Reinhardt, J. (2020). Metaphors for social media-enhanced foreign language teaching and learning. Foreign Language Annals, 53(2), 234-242. https://doi.org/10.1111/flan.12462

Ross, A. F., \& DiSalvo, M. L. (2020). Negotiating displacement, regaining community: The Harvard Language Center's response to the COVID-19 crisis. Foreign Language Annals, 53(2), 371-379. https://doi.org/10.1111/flan.12463

Shrum, J. L., \& Glisan, E. W. (2010). Teacher's Handbook: Contextualized language instruction (4th ed.). Heinle Cengage Learning.

Sue, V., \& Ritter, L. (2007). Conducting online surveys. Sage Publications. https://doi.org/10.4135/9781412983754

The Education Council (2018). The national strategy for education 2040. https://www.educouncil.gov.om/downloads/Ts775SPNmXDQ.pdf

Thomas, M., Reinders, H., \& Warschauer, M. (Eds.). (2013). Contemporary computer-assisted language learning. Bloomsbury.

Vai, M., \& Sosulski, K. (2011). Essentials of online course design: A standards-based guide. Routledge Taylor and Francis Group. https://doi.org/10.4324/9780203838310

Vehovar, V., \& Manfreda, K., L. (2017). Overview: Online surveys. In N.G. Fielding, R.M. Lee, \& G. Blank (Eds.), The Sage handbook of online research methods (2nd ed., pp. 143-161). The Sage Publications. https://doi.org/10.4135/9781473957992.n9

\section{Copyrights}

Copyright for this article is retained by the author(s), with first publication rights granted to the journal.

This is an open-access article distributed under the terms and conditions of the Creative Commons Attribution license (http://creativecommons.org/licenses/by/4.0/). 